\title{
Effects of Sustainable Strategic Planning Applications in Primary Schools on the Effectiveness of Total Quality Management Practices
}

\author{
Esen Sucuoğlu * and Gülümser Erdem \\ Education Faculty, Near East University, 99138 Nicosia, Turkey; gulumsererdem1@gmail.com \\ * Correspondence: esen.sucuoglu@neu.edu.tr
}

\begin{abstract}
This paper addresses the evaluations of administrators and teachers working in primary schools of sustainable strategic planning practices in schools and their perceptions of the effectiveness of total quality management (TQM) practices. This study followed the quantitative research approach and was limited to primary schools in Ankara, Turkey. A face-to-face survey was conducted, and 400 responses were obtained from administrators and teachers working in primary schools. The hypothesis was tested using path analysis. The findings confirm that strategic planning practices in schools make a significant contribution to enhancing the perception of the effectiveness of TQM practices. The findings of the study and their implications are expected to benefit the development of primary schools in Turkey.
\end{abstract}

Keywords: TQM; education; strategic planning; primary schools; Turkey

Citation: Sucuoğlu, E.; Erdem, G. Effects of Sustainable Strategic Planning Applications in Primary Schools on the Effectiveness of Total Quality Management Practices. Sustainability 2021, 13, 9998. https:// doi.org/10.3390/su13189998

Academic Editor: Gisela Cebrián

Received: 18 June 2021

Accepted: 26 August 2021

Published: 7 September 2021

Publisher's Note: MDPI stays neutral with regard to jurisdictional claims in published maps and institutional affiliations.

Copyright: (c) 2021 by the authors. Licensee MDPI, Basel, Switzerland. This article is an open access article distributed under the terms and conditions of the Creative Commons Attribution (CC BY) license (https:// creativecommons.org/licenses/by/ $4.0 /)$.

\section{Introduction}

Today, the concept of sustainable development is the key issue in all documents at global, European, and even national levels, including educational development planning guidelines. Sustainability has become a decisive factor in the choice of strategy and the preparation of development, action, and investment plans. Sustainable development planning involves the use of many variables, forecasting, and applying a systematic approach. Primary schools develop their long-term sustainable development strategies for a certain period of time. In this case, a primary school's sustainable strategic plan can be considered as the cornerstone of an educational institution. In addition to defining a plan, it is indispensable to define strategic planning missions, principles, and, most importantly, vision and values $[1,2]$.

The concept of strategic planning, which is generally used for economic systems and is defined as a set of decisions made for the most effective and efficient use of resources in production to be made in accordance with the needs of the target audience, is of great importance in the education system $[3,4]$. With strategic planning, it is possible for educational institutions to determine their goals and objectives, define their mission and vision, and systematically express the short- and long-term paths they will follow.

Moreover, educational institutions may adapt to the changing external environmental conditions, come to the forefront in the competition, and train individuals who are more successful and experts in their fields by including the quality process in their strategic planning [5]. TQM that aims for quality, not only at the last stage of production but in all institutional processes, is a concept that permeates all functions (i.e., marketing, accounting, finance, human resources, public relations, and management) of institutions, and at the same time covers all employees and instils responsibility. Therefore, using the concept of TQM in educational institutions is important in terms of training qualified personnel who can meet both individual and social demands and needs. In other words, when dynamic environmental conditions are taken into consideration, situational factors-such 
as increased communication with advanced technology tools, lifelong learning, effective and efficient learning, the emergence of concepts such as learning to learn, the demand for a more qualified workforce, and the desire to upgrade teachers' qualifications-make it almost compulsory to make strategic planning in educational institutions, which includes the philosophy of TQM [6-8].

In this study, the importance of strategic planning and TQM in the education sector is discussed, and how it was perceived by administrators is determined. Within the conceptual framework of the study, the concept of strategy is examined, and the importance and process of strategic planning in institutions are highlighted. Along with the concept of total quality, the methods for applying the TQM philosophy in education are explained.

This study aims to fill a gap in the literature about the relationship between the evaluations of administrators and teachers of strategic planning practices in primary schools and their perceptions of the effectiveness of TQM practices. Previous studies have examined the direct relationships between TQM practices and teacher performance [9], TQM practices and teacher training [10], and TQM practices and teacher motivation [11]. The current study provides the first empirical evidence of a direct relationship between TQM practices and strategic planning practices.

\section{Theoretical Background and Research Hypothesis}

Education, which is defined as the process of differentiating and developing human behaviours permanently in accordance with certain purposes, must be established with strategic plans within the framework of total quality to be long term, permanent, and healthy. Strategic decision making and planning in educational institutions are considered as a whole and are developed to serve the main objective of the institution. The strategic decisions and plans determined and established by the administrators of the educational institution are especially established in accordance with the vision and mission of the institution and are synchronised with the policies to be implemented. In other words, the concept of strategic management is a set of methods determined according to the steps taken to achieve the mission and vision of educational institutions and their goals and objectives [12].

Planning in education can also be defined as a set of decisions made by considering the budget to be allocated to fulfil the needs of students and the economic and political conditions of the work to be conducted $[13,14]$. In making a national education plan, it is necessary to determine the demographic structure of the country, the resources allocated for education, the functioning of the education system and the statistics of employee performance. In determining these statistics, priority is given to short-, medium-, and long-term data. These data include lifelong learning, the need for scientifically qualified employees, the rate of literacy, and the educational needs of the sectors. It is important for decision makers and school administrators to acquire many competencies in the concept of planning and to become experts in their subjects [15].

In addition to the analysis of strategic planning in education, the desires and needs of the stakeholders (i.e., parents, students, teachers, school administrators, and other internal and external environmental factors) involved in the planning process should also be taken into account. In this way, strategic planning can be placed on solid ground, and, at the same time, significant steps can be taken in achieving their goals. An opportunity is created to ensure the sustainability of planning $[16,17]$. Strategic planning in the education sector has four main features [18]:

- Although education is a production instrument with its expertise, skills, personality development, modernity, and certain technical features, it is also considered a consumption tool because of the learning needs of society.

- Education aims to increase the welfare of society through the development of individuals.

- Educational efficiency varies according to a country's level of economic and social development. 
- Measuring educational efficiency only quantitatively is not sufficient. It should be evaluated as a whole using qualitative measurements.

The strategic planning process in education, which emerged in higher education institutions in the 1970s, was adapted to the entire education system after the 1980s and put into practice [19]. Five-year development plans and central government budgets and programs are among the tools used in preparing education planning in Turkey [20]. All elements, such as operations in the strategic planning process in educational institutions, all human and technical resources, the responsibilities of stakeholders, and the costs to be incurred, are included in the Ministry of National Education's (MoNE) strategic planning model. The strategic planning model applied in the Turkish education system is the planning model predicted by State Planning Organization (SPO). It is taken as a basis in all schools and educational institutions and indicates that the strategic plan is predicted to be prepared accordingly. By further developing the 2015-2019 Strategic Plan Monitoring and Evaluation Model, the MoNE of the Republic of Turkey created the MoNE 2019-2023 Strategic Plan and proposed this model. In this new model, the following principles are prioritised: transparency, accountability, scientific approach objectivity, and participation.

The processes of the 2019-2023 Strategic Plan Monitoring and Evaluation Model developed within the framework of these principles are as follows:

- Realising performance criteria in line with strategies.

- Comparing performance criteria with goals and objectives.

- Creating the distribution of the strategies prepared in educational institutions according to the fields of the ministries.

- Presenting the evaluation results in a report and sharing them with all stakeholders.

- Determining whether the goals and objectives have been achieved, measuring effectiveness and efficiency, and revealing the reasons if the desired goals have not been achieved.

- Developing alternative strategies and creating solutions or recommendations.

The success of an educational institution is based on different criteria. One of these is the process of integrating the understanding of TQM into the institution. The effectiveness of educational institutions is evidenced by their ability to provide the best conditions for learning by providing quality services. Therefore, TQM is based on service quality in educational institutions. Although educational institutions aim to ensure the satisfaction of their employees and customers, their primary objective is to increase the welfare and development levels of society. TQM, which is a cultural revolution of a way of thinking focused on continuous quality improvement, is a set of techniques to improve, develop, and innovate all activities and methods of the organisation and to bring the institution to perfection [21].

The main purpose of TQM is to determine the understanding of quality that appeals to the demands and needs of customers and to launch products according to this. Therefore, TQM is included in strategic planning in today's education sector and is preferred to the traditional approach. When implementing TQM in education, the most important part for institutions and organisations is to determine their goals and objectives to be achieved, make appropriate plans, and formulate policies at this point [22]. The synchronicity of the objectives, the plans created, and the participation of all employees should be considered. All plans and strategies should be announced and adopted by all employees. Afterward, the audit and control phase, which constitutes a large part of TQM, begins. The involvement of administrators at this stage determines the support given to TQM. One of the most important factors that advances education is identifying the existing conditions and improving them, or, in other words, transitioning to the improvement process. Within this factor, good management of the process is important. This requires accurate information and data that can clearly reveal facts. Obtaining these data depends on using the correct measurement technique. Three different measurement techniques are used in educational institutions: the customer satisfaction index (CSI), employee satisfaction index (ESI), and other quality measures related to the internal processes of 
educational institutions. To achieve better quality education, real data should be collected continuously using the correct measurement technique, and they should be analysed and reported properly $[23,24]$.

Aside from these techniques, other methods, such as the expert approach (Deming and Crosby methods), the Japanese model approach, the Hoshin planning approach, the Malcolm Baldrige Award approach, the European Quality Award (EFQM) approach, and the industry model approach are used in the adaptation of TQM to education [25].

The expert approach is important for understanding TQM. Two important methods attract attention toward this approach. The first is Deming's quality rules, created by Deming. These rules defend the need for a clear expression of the understanding of TQM and the adaptation of this philosophy to the educational institution. They are based on a clear expression and implementation of the PDCA cycle (plan, do, check, act) as the cycle of continuous improvement prevails in education. The second method is the 14 basic rules of Crosby, which indicate the importance of the management to be directly involved in the quality development process, to establish quality improvement teams within organisations, to determine all necessary control and measurement tools and criteria, to state the quality costs clearly, to train all employees for the understanding of quality, to establish regulations for errors and problems that occur within the institution, to establish a commission for the concept of zero defects and to instil its awareness, to organise continuous training that will improve the understanding of total quality, to clarify the goals and objectives of institutions, to arrange the distribution of tasks according to these goals and objectives, to strengthen internal communication, and to ensure regular information flow. The Japanese model approach is used in the adaptation of total quality understanding to education. This approach is based on statistical controls and covers the entire organisation. It is designed according to the Deming Award, which is widely adopted by Japanese companies. The Japanese model approach is applicable to all institutions, and it includes basic criteria, such as determining the plans and policies for the objectives, establishing and managing organisations, developing the quality control system, establishing the quality information network, statistical analysis, standardisation, auditing, quality assurance, and determining the vision of educational institutions [26]. The Malcolm Baldrige Award approach was created in 1989 in the United States and is applied in educational institutions. This approach includes the following criteria: strategic quality planning, leadership, focus on students and external stakeholders, focus on teachers and other administrators (i.e., focus on employees and customers), statistical data analysis, and performance. The EFQM model has similar criteria to the KALDER Award in Turkey, such as establishing training strategies and policies, leadership, human resources management, employee and customer satisfaction, and internal and external environment benefits. In the industry model approach, successful strategy applications, which are generally based on manufacturing and production enterprises, are synchronised with educational institutions. This approach creates a model based on the production process and output, that is, the educational process and the structure of graduate students [27]. The Hoshin planning approach, which was developed by Bridgestone Company, is based on good planning, adaptation to the whole organisation, careful implementation, and control in certain periods (usually every month). This approach is used in both long- and short-term strategic plans, especially in educational institutions.

In the literature review, no study has been found to evaluate education sector employees regarding strategic planning practices in schools or the perceptions of education sector employees regarding the effectiveness of TQM practices. Examining the possible causal relationships between TQM practices and strategic planning is important, and the effects of strategic planning practices on TQM practices in evaluating the efficiency of these practices should be determined. Therefore, the following hypothesis was developed to fill this research gap: 
Hypothesis 1. The evaluations of administrators and teachers working in primary schools with strategic planning practices positively affect their perceptions of TQM practices.

\section{Materials and Methods}

\subsection{Questionnaire Design}

The survey instruments for each construct were designed to gather exhaustive details. The following survey instruments were adapted from the literature: The Strategic Planning Practices at Schools Scale, which has three dimensions and 22 items [19], and the Perception of TQM Practices Scale, which has six items [9]. A five-point Likert-type scale was used to measure the responses.

The initial content validation was carried out by four experts in the field of education who have significant experience of management practices relating to the different educational programs at the primary education level.

In order to test the reliability of the questionnaire (that is, the degree to which the questionnaire produces stable and consistent results) before the hypothesis are tested, the reliability of the measurement scales should be checked. In general, the reliability of the construct should be greater than 0.7 in order to meet the general requirement of reliability for research instruments [26]. It is found that the Cronbach's alpha values for the independent variable and dependent variable are 0.856 and 0.791 respectively, confirming reliability.

\subsection{Survey Administration}

This research was based on an online survey conducted between 15 February 2021 and 28 February 2021 on 400 randomly chosen teachers and/or administrators of primary schools in Ankara, Turkey. The participants were reached through the EMA Research Company. The population of primary school teachers and administrators in Ankara Province is 27,000, consisting of about 15,000 woman and 12,000 men. Participants had volunteered to participate in the study. The participants were first contacted via e-mail, and they were subsequently informed about the aim of the research and asked for their consent to be interviewed.

Research Participants

The sample consisted of 290 primary school teachers, 80 primary school deputy directors and 30 primary school directors. The average duration of employment of the samples was $11-15$ years (standard deviation $=9.78$ ). A large percentage of the sample was employed in public schools (87\%). The average monthly income of the sample was TRY 6000 (standard deviation $=10.65)$. Most of the sample $(93 \%)$ had undergraduate degree qualifications.

\subsection{Data Analysis}

Path analysis was employed to determine the causal relationships for theory confirmation. Lisrel 9.1 and SPSS 25 were used in the data analysis.

\section{Results}

The measurement model was assessed through factor loading, Cronbach's alpha (CA), composite reliability (CR), average variance extracted (AVE), convergent validity, and discriminant validity. The $C A$ values for all the constructs were greater than the satisfactory level of 0.7, indicating good internal consistency for each construct. The CR value was greater than 0.65 . Both test results confirmed the internal consistency and reliability of the measures. Convergent validity was ensured by examining the outer loadings of the items in each construct, as the AVE value was greater than 0.5. According to [27], an outer loading of $<0.40$ should be eliminated, while a value of $>0.70$ is acceptable. All item loadings were statistically significant $(t$-value $>1.96$; Figure 1$)$. 


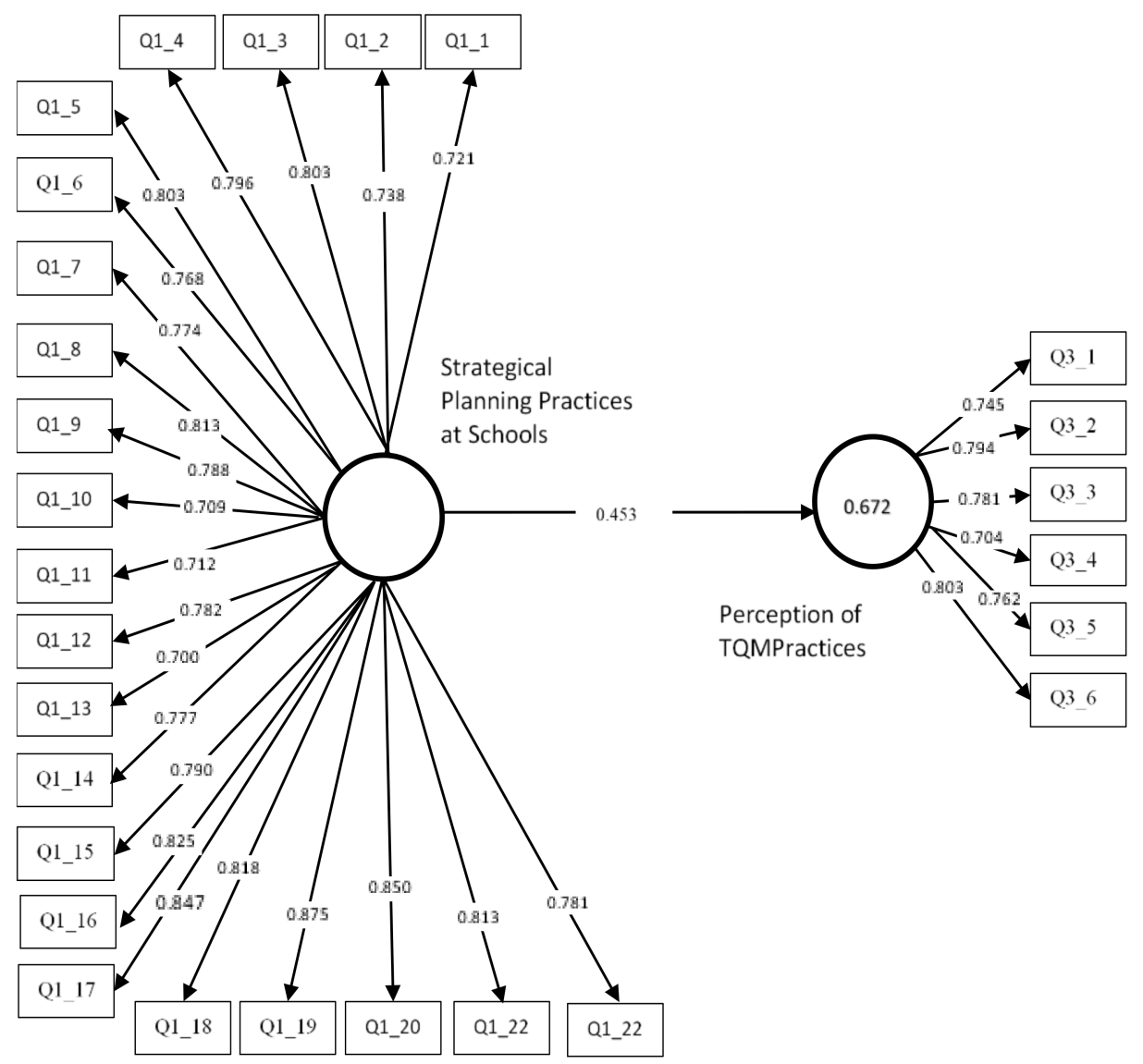

Figure 1. Measurement model assessment.

The discriminant validity was evaluated using the Fornell-Larcker criterion, the heterotrait-monotrait (HTMT) ratio of correlation, and the cross-loading of the indicator. First, the Fornell-Larcker criterion was used. This method compares the square root of the AVE with the correlation of the latent constructs [28]. A latent construct should better explain the variance of its own indicator rather than the variance of other latent constructs. Therefore, the square root of each construct's AVE should be greater than the highest correlation value for the other latent constructs.

In cross-loading, the factor loading indicators on the assigned construct should be higher than those of other constructs under the condition that the cut-off value of the factor loading is higher than 0.70 (Table 1) [29,30].

Table 1. Composite reliability (CR), square root of the average variance extracted (AVE) (in bold) and correlations between constructs (off-diagonal).

\begin{tabular}{cccccc}
\hline Latent Constructs & CA & CR & AVE & $\mathbf{0 1}$ & $\mathbf{0 2}$ \\
\hline Strategical Planning Practices at Schools & 0.856 & 0.879 & 0.701 & $\mathbf{0 . 7 5 3}$ & \\
Perception of TQM Practices & 0.791 & 0.809 & 0.728 & 0.711 & $\mathbf{0 . 7 3 2}$ \\
\hline
\end{tabular}

The second measure for discriminant validity is the HTMT ratio of correlation. Basar and et al [29] proposed that the performance of this method was superior. Using the Monte Carlo simulation, they found that HTMT achieved higher specificity and sensitivity rates (97-99\%) than the cross-loading (0.00\%) and Fornell-Larcker (20.82\%) criteria.

HTMT values close to one indicate a lack of discriminant validity. Using HTMT as a criterion involves comparing it to a predefined threshold. There is a lack of discriminant validity when the value of the HTMT is higher than this threshold. Kline suggested a 
threshold of 0.85 [31]. In this study, the HTMT value was 0.469 and did not exceed 0.85 . Thus, discriminant validity was established between the reflective constructs.

The third measure is the cross-loading values of the items. Table 2 shows that the item loadings for their own constructs are relatively higher than the loadings for the other constructs, confirming the discriminant validity of the items.

Table 2 shows the discriminant validity, which attained external consistency.

Table 2. Cross-loadings of items.

\begin{tabular}{|c|c|c|}
\hline Items & $\begin{array}{l}\text { Strategical Planning } \\
\text { Practices at Schools }\end{array}$ & $\begin{array}{l}\text { Perception of } \\
\text { TQM Practices }\end{array}$ \\
\hline Q1_1. School administrators have sufficient knowledge about strategic planning. & 0.721 & 0.694 \\
\hline Q1_2. Our school is managed in accordance with strategic planning. & 0.738 & 0.642 \\
\hline Q1_3. The management approach of our school facilitates strategic planning. & 0.803 & 0.709 \\
\hline Q1_4. Our school receives adequate guidance and counselling regarding strategic planning. & 0.796 & 0.638 \\
\hline Q1_5. Our school has a regular strategic planning policy. & 0.803 & 0.687 \\
\hline Q1_6. The strategic plan preparation team is well trained in plan preparation. & 0.774 & 0.691 \\
\hline Q1_7. School staff eagerly participate in strategic planning activities. & 0.774 & 0.596 \\
\hline $\begin{array}{l}\text { Q1_8. The strategic plan is prepared by determining realistic goals, principles, resources, and } \\
\text { achievements. }\end{array}$ & 0.813 & 0.613 \\
\hline Q1_9. A comprehensive situation analysis is performed in the strategic planning process. & 0.788 & 0.601 \\
\hline Q1_10. Parents participate in strategic planning activities. & 0.709 & 0.552 \\
\hline Q1_11. Teachers support the strategic planning process. & 0.712 & 0.568 \\
\hline Q1_12. Students are encouraged to participate in the strategic planning process. & 0.782 & 0.596 \\
\hline Q1_13. Adequate preparation is made before strategic planning. & 0.700 & 0.613 \\
\hline Q1_14. The strategic plan is constantly evaluated and revised. & 0.777 & 0.601 \\
\hline Q1_15. The opportunities specified in the strategic plan are evaluated in the best way. & 0.790 & 0.487 \\
\hline Q1_16. School personnel are insensitive to strategic planning studies. (reverse) & 0.825 & 0.512 \\
\hline Q1_17. Not enough time is allocated for the development of the strategic plan. (reverse) & 0.847 & 0.500 \\
\hline Q1_18. School staff do not believe that the prepared strategic plan will be implemented. (reverse) & 0.818 & 0.534 \\
\hline Q1_19. Administrators do not consider strategic planning practices necessary in school. (reverse) & 0.875 & 0.525 \\
\hline $\begin{array}{l}\text { Q1_20. Conditions of the environment and the school are ignored when preparing strategic plans. } \\
\text { (reverse) }\end{array}$ & 0.850 & 0.565 \\
\hline $\begin{array}{l}\text { Q1_21. Strengths and weaknesses of the school are not determined realistically in the strategic } \\
\text { plans. (reverse) }\end{array}$ & 0.813 & 0.512 \\
\hline $\begin{array}{l}\text { Q1_22. The weaknesses and threats to the school determined in the strategic plan are ignored in } \\
\text { practice. (reverse) }\end{array}$ & 0.781 & 0.500 \\
\hline $\begin{array}{l}\text { Q2_1. School staff's ability to communicate well horizontally and vertically contributes to their } \\
\text { motivation. }\end{array}$ & 0.745 & 0.459 \\
\hline $\begin{array}{l}\text { Q2_2. A clear knowledge of the roles and responsibilities of all staff in school increases the } \\
\text { efficiency of their work. }\end{array}$ & 0.794 & 0.691 \\
\hline $\begin{array}{l}\text { Q2_3. Following new developments in teaching methods and techniques and adapting them to the } \\
\text { school contribute to the work performance of staff. }\end{array}$ & 0.781 & 0.703 \\
\hline $\begin{array}{l}\text { Q2_4. Rewarding school staff for their efforts to improve themselves and the institution creates } \\
\text { synergy in the institution. }\end{array}$ & 0.704 & 0.661 \\
\hline $\begin{array}{l}\text { Q2_5. All kinds of changes (social, economic) affecting the education process should be closely } \\
\text { monitored, and measures should be taken against possible effects. }\end{array}$ & 0.762 & 0.671 \\
\hline $\begin{array}{l}\text { Q2_6. Regular meetings should be held to identify potential obstacles to the educational } \\
\text { environment in advance. }\end{array}$ & 0.803 & 0.602 \\
\hline
\end{tabular}

Figure 1 shows that the perception of TQM practices explains $67 \%$ of the variance of the independent construct. The construct is statistically significant $(p<0.05)$. The normalised fit index is 0.78 (value closer to 1 ). The standardised root mean square residual 
value is 0.05 (value $<0.08$ ). The goodness-of-fit value is the square root of the product of average AVE and average R2. This study's good-of-fit value of 0.575 (value $>0.36$ ) is considered satisfactory for model fit indices, confirming its predictive validity [28].

The results show that the path coefficient is statistically significant using all data set bootstrap samples with a $95 \%$ confidence interval (the causal hypothesis is confirmed; Table 3).

Table 3. Hypothesis.

\begin{tabular}{ccccc}
\hline Causal Hypothesis & $\boldsymbol{\beta}$ & $\mathbf{t}$ & $\boldsymbol{p}$ & Results \\
\hline H1 & 0.453 & 3.234 & 0.000 & Accepted \\
\hline
\end{tabular}

\section{Discussion and Conclusions}

The main purpose of this study was to determine whether the evaluations of administrators and teachers working in primary schools of strategic planning practices in schools affect their perceptions of the effectiveness of TQM practices. Thus, this study proposed a causal hypothesis. The research framework was validated, and statistically significant results were found for the hypothesis using path analysis.

In summary, the results show positive and significant effects of strategic planning practices in schools $(\beta=0.453, p<0.01)$ on the perception of TQM practices, thus supporting H1.

The analysis shows the effect of strategic planning practices in schools on the perceptions of TQM practices. The application of path analysis in this work provided in-depth insight into the effect pathway, which showed how strategic planning practices in schools affect the perceptions of TQM by administrators and teachers working in primary schools. Strategic planning practices in schools were found to be essential in forming TQM practices.

\subsection{Implications of the Study}

\subsubsection{Theoretical Implications}

These results offer several implications for the literature. First, the relationship between strategic planning practices in schools and the perception of TQM practices plays a vital role in the literature because it is unique, as examined in the current study. This relationship contributes significantly to the literature on strategic planning practices in schools and the perception of TQM practices. Second, this work is a pioneer study that examined strategic planning practices in primary schools in Turkey. Strategic planning practices are rare in primary schools. Specifically, strategic planning practices are addressed in relation to TQM practices, which are rarely addressed in Turkey primary schools. Third, previous studies have not discussed strategic planning practices, which are one of the unique variables investigated in relation to TQM practices.

\subsubsection{Practical Implications}

The relationship between strategic planning practices in schools and the perception of TQM practices has several implications for practitioners. First, this study highlighted that administrators and teachers working in primary schools play a major role in enhancing their perceptions of TQM practices in strategic planning practices in schools. Therefore, the management of strategic planning practices can enhance TQM practices by promoting administrators and teachers working in primary schools. The most important implication of this study is connected to strategic planning practices in primary schools. This study proved that strategic planning practices in schools are a key factor in the perception of TQM practices by administrators and teachers working in primary schools.

\subsection{Sustainability Remarks}

In a context where the concept of sustainability has become so important, representing one of the columns of social and economic development and a new challenge to excellence 
for any school that is widely accepted to play a teaching role, teachers and administrators have been called to extend their activities, presenting themselves as operators for social change [32].

Schools need to address and evaluate the sustainability of the values, syllabuses, and techniques that they use in educational activities in the education processes. Quality control and strategic planning are no longer enough for most schools' educational activities. Sustainability control and sustainability assurance needs to be built into every educational process of their activities in order to be ultimately prosperous in today's and tomorrow's world.

\subsection{Limitations and Future Directions}

Although this research provides new evidence and covers the major areas in strategic planning practices in schools and the perception of TQM practices, it also has some limitations that can be addressed in future studies. As the sample size in this study is limited, the sample is not representative of all administrators and teachers working in primary schools in Turkey. Larger sample sizes could give more evidence of the generalisability of results. Moreover, this study included only strategic planning practices. Administrator and teacher performance is one of the most important aspects of TQM practices. Therefore, future studies should also include new constructs, such as administrator and teacher performance, in the current model.

Author Contributions: Conceptualization, G.E.; Methodology, G.E.; Supervision, E.S.; Writingreview \& editing, E.S. and G.E. Both authors have read and agreed to the published version of the manuscript.

Funding: This research received no external funding.

Institutional Review Board Statement: The study was conducted according to the guidelines of the Declaration of Helsinki, and approved by the Institutional Ethics Committee) of NEAR EAST UNIVERSITY.

Informed Consent Statement: Informed consent was obtained from all subjects involved in the study.

Data Availability Statement: Not applicable.

Conflicts of Interest: The authors declare no conflict of interest.

\section{References}

1. Luce, I. Sustainable strategic planning principles of colleges. In Proceedings of the Economic Science for Rural Development Conference Proceedings, Riga, Latvia, 28 May 2018; Volume 47, pp. 183-188. [CrossRef]

2. Karaca, A. Connection of architectural education with the technological world in Northern Cyprus. Int. J. New Trends Soc. Sci. 2020, 4, 36-50. [CrossRef]

3. Tabatabei, E. Innovative, creative VARK learning styles improvement strategies. Glob. J. Foreign Lang. Teach. 2018, 8, 87-93. [CrossRef]

4. Jabbar, M.N.; Hussin, F. Quality management as a strategic tool to enhance the relationship between leaders' behavior and lecturers' job satisfaction. Int. J. Curr. Innov. Interdisip. Sci. Stud. 2019, 3, 1-15. Available online: https://www.un-pub.eu/ojs/ index.php/IJ-CISS/article/view/5033 (accessed on 25 May 2021). [CrossRef]

5. Mabrouk, E.H. Problems and strategy of educational development in Morocco. New Trends Issues Proc. Humanit. Soc. Sci. 2019, 6, 430-439. [CrossRef]

6. Uhlirova, M. Semantic space of elementary teacher attitudes towards computer teaching assistant. Glob. J. Inf. Technol. Emerg. Technol. 2018, 8, 1-9. [CrossRef]

7. Kelkay, A.D.; Mola, S. The status of teachers' motivation and process of quality education: The case of primary school teachers, Ethiopia. Glob. J. Guid. Couns. Sch. Curr. Perspect. 2020, 10, 1-11. [CrossRef]

8. Kubieva, V.; Sagiyeva, A.; Sagiyeva, A.; Salimgerey, Z.; Baiseitova, M. Multilingualism is a trend in the development of modern Kazakhstan. Glob. J. Sociol. Curr. Issues 2021, 11, 40-44. [CrossRef]

9. Tahtabaş, M. Toplam Kalite Yönetimi Uygulamaları ile Öğretmen Performansı Arasındaki İlişkinin Belirlenmesi (Öğretmen Görüşlerine Göre). Determining the Relationship between Total Quality Management Practices and Teacher Performance (According to Teacher Opinions). Master's Thesis, Yeditepe University, Istanbul, Turkey, 2009. Unpublished.

10. Chauhan, A.; Sharma, P. Teacher education and total quality management (TQM). Int. J. Indian Psychol. 2015, 2, 80-85. Available online: https: / / tinyurl.com/yeztq9az (accessed on 12 March 2021). 
11. Mahmood, H.K.; Hashmi, M.S.; Shoaib, D.M.; Danish, R.; Abbas, J. Impact of TQM practices on motivation of teachers in secondary schools: Empirical evidence from Pakistan. J. Basic Appl. Sci. Res. 2014, 4, 1-8. Available online: https://tinyurl.com/yhbjn9dx (accessed on 13 February 2021).

12. Ereş, F. Eğitim yönetiminde stratejik planlama. Strategic planning in educational administration. Gazi Univ. J. Ind. Arts Educ. Fac. 2004, 15, 21-29. Available online: https:/ / dergipark.org.tr/en/download/article-file/296511 (accessed on 14 June 2021).

13. Ergen, H. Planning approaches in education and educational indicators used in Turkey. Mersin Univ. J. Fac. Educ. 2013, 9, 151-167. Available online: https:/ / dergipark.org.tr/en/pub/mersinefd/issue/17383/181588 (accessed on 9 January 2021).

14. Safaryan, N. Methodological issues of education monitoring and evaluation. Int. J. Learn. Teach. 2020, 12, 176-183. [CrossRef]

15. Karatürk, K. Eğitim Planlaması. Education Planning; Pegem Akademi: Ankara, Turkey, 2019.

16. Şahin, S.; Aslan, N. A qualitative study on the opinions of secondary school principals regarding strategic planning. Gaziantep Univ. J. Soc. Sci. 2008, 7, 172-189. Available online: https://dergipark.org.tr/en/pub/jss/issue/24257/257122?publisher=gantep (accessed on 15 March 2021).

17. Abdi, M.; Sharyati, A. Comparing the training effects of problem-solving and coping skills with stress. Glob. J. Psychol. Res. New Trends Issues 2019, 9, 16-22. [CrossRef]

18. Çalık, T. Strategical planning in education and the qualitative evaluation of the schools as regards to strategical planning. Kast. J. Educ. 2003, 11, 251-258. Available online: https:/ / tinyurl.com/yjofpob6 (accessed on 29 March 2021).

19. Memduhoğlu, H.B.; Uçar, İ.H. Developing the Strategic Planning Perception Scale and the Strategic Planning Application Assessment Scale in School. Educ. Adm. Theory Pract. 2012, 18, 545-574. Available online: https://dergipark.org.tr/en/pub/ kuey/issue/10322/126575 (accessed on 8 January 2021).

20. Gümüş, E.; Şişman, M. Eğitim Ekonomisi ve Planlaması; Pegem Yayınları: Ankara, Turkey, 2012. Available online: https://tinyurl. com/yk5ks3hv (accessed on 17 January 2021).

21. Agha, Z.; EL Daou, B. The role of the special education centers in developing students' holistic wellbeing. J. Educ. Spec. Educ. Technol. 2018, 4, 1-13. [CrossRef]

22. Alkhateeb, M.A. The Effect of Using Performance-based assessment Strategies to Tenth Grade Students' Achievement and Self-Efficacy in Jordan. Cypriot J. Educ. Sci. 2018, 13, 489-500. [CrossRef]

23. Yıldız, G.; Ardıç, K. Eğitimde toplam kalite yönetimi. Total quality management in educatio. Bilgi J. Soc. Sci. 1999, 1, 73-82. Available online: https:/ / dergipark.org.tr/en/download/article-file/301065 (accessed on 19 February 2021).

24. Sallis, E. Total Quality Management in Education; Routledge: New York, NY, USA, 2002; Volume 3.

25. Konst, T.; Kairisto-Mertanen, L. Developing innovation pedagogy. Contemp. Educ. Res. J. 2019, 9, 74-84. [CrossRef]

26. Chen, M. Attitude toward organic foods among Taiwanese as related to health consciousness, environmental attitudes, and the mediating effects of a healthy lifestyle. Br. Food J. 2009, 111, 165-178. [CrossRef]

27. Hair, J.F., Jr.; Hult, G.T.M.; Ringle, C.; Sarstedt, M. A Primer on Partial Least Squares Structural Equation Modeling (PLS-SEM), 2nd ed.; Sage Publications: Los Angeles, CA, USA, 2014.

28. Hair, J.F.; Ringle, C.M.; Sarstedt, M. PLS-SEM: Indeed, a silver bullet. J. Mark. Theory Pract. 2011, 19, 139-152. [CrossRef]

29. Başar, Ş.; Başar, E.E. How does the environmental knowledge of Turkish households affect their environmentally responsible food choices? The mediating effects of environmental concerns. Int. J. Agric. Environ. Food Sci. 2020, 4, 348-355. [CrossRef]

30. Henseler, J.; Ringle, C.M.; Sarstedt, M. A new criterion for assessing discriminant validity in variance-based structural equation modeling. J. Acad. Mark. Sci. 2015, 43, 115-135. [CrossRef]

31. Kline, R.B. Principles and Practice of Structural Equation Modeling, 3rd ed.; The Guilford Press: New York, NY, USA, 2011.

32. Fantauzzi, C.; Colasanti, N.; Fiorani, G.; Frondizi, R. Sustainable strategic planning in Italian higher education institutions: A content analysis. Int. J. Sustain. High. Educ. 2021, 22, 1145-1165. [CrossRef] 